ACQUISITIONS

- The Principal of Queen's University, Kingston, Ontario, Dr. John J. Deutsch, has announced that he is presenting his papers to the QuEEN's UNIVERstry archives. The correspondence, notes, memoranda, and other files accumulated by Dr. Deutsch during his career already are being transferred to the archives, where they will be sorted, inventoried, preserved, and eventually made available to rescarchers. The papers reflect the varied aspects of his work and will add new dimensions to the official records.

Dr. Deutsch has taken a prominent part in many governmental commissions. He was assistant director of research for the Rowell-Sirois Commission (1937-40), and was a member of the Royal Commission on Newfoundland finances (1947), the Special Senate Committee on Manpower and Employment (1960), and the Special Commission of Inquiry into the Unemployment Insurance Act (1961). Also in 1961, Dr. Deutsch was appointed chairman of a Royal Commission which studied higher education in New Brunswick. The result was the reorganization of the province's university system. In 1962, he was chairman of a committee which performed the same service for Ontario.

- The WV. A. Bell library of Miles College, Birmingham, Alabama, has been presented with more than 3,000 volumes from the private library of the late Dr. Clinton Rossiter of Ithaca, New York. Dr. Rossiter, well-known political scientist, historian, lecturer, writer, and the John L. Senior Professor of American Institutions at Cormell University, was one of the foremost authorities on American constitutional history and political theory. A member of the Cornell faculty since 1946, Dr. Rossiter taught and lectured in many parts of the world and served as a consultant to the Fund for the Republic and Rockefeller Foundations. He has published numerous books, among them: The Supreme Court and the Commander in Chief; Constitutional Dictatorship; Conservatism in America; The American Presidency; Parties and Politics in America; Marxism: The View from America; and Alexander Hamilton and the Constitution.

- The estate of Professor Joseph T. Tykociner, a pioneer in the field of wireless, electronics, sound movies, and the new field of zetetics, has given his papers to the archives of the UNIVERSITY OF ILliNoIs at Urbana-Champaign. A sixty-ninc-page inventory lists corre- spondence, notes, books, articles and reprints, photographs and negatives, biographical materials, and sound tapes that are to be found in the collection. The contents of the collection have been reported to the National Union Catalog of Manuscripts Collections in the Library of Congress and to the National Catalog of Sources for History of Physics compiled by the American Institute of Physics.

- A significant gift of rare and early dictionaries has been presented to Indana STATE UNIversity Cunningham Memorial library by Warren N. Cordell, Chicago businessman and ISU alumnus, and his wife, Suzanne. The initial gift of approximately 450 items (600 volumes) has been received and some 2,000 volumes will be transferred to the library at a later date.

ISU President Alan C. Rankin has announced that as a supplement to the Cordell gift, the National Endowment for Humanities Foundation has awarded the University $\$ 66,500$, an amount that matches the value of this portion of the collection. The grant will allow the ISU library to develop and maintain this rare book collection and to make it available to scholars and the public.

Editions of the famous Samuel Johnson's A Dictionary of the English Language from the first folio (1755) through the seventh (1786) form the keystone of the Cordell collection. Also included are Johnson's first American edition (1818), quarto editions, octavo editions from the first (1756) through the eleventh (1799), various nineteenth century editions, and miniature editions. Fighteenth and nineteenth century Johnson editions now at ISU total 102 and, of these, thirty-four are pre-1800. A particularly rare item is a fine, first edition copy of his The Plan of a Dictionary (1747). Another outstanding part of the Cordell collection is the section of Latin-English Renaissance dictionaries.

Supplementing the Cordell collection is the recently acquired collection of 102 rare and early English and American dictionaries from a California collector, Gene Freman. This collection represents the first major purchase to strengthen the Cordell collection.

The most noteworthy items are two early American dictionaries: the first edition of Noah Webster's A Dictionary of the English Language Compiled for the Use of the Common Schools in the United States, 1807; and the first English edition of his Dictionary of the English Language ("American Dictionary"), 1830. Other key American dictionaries include first editions of Joseph E. Worcester's Johnson's English Dictionary, 1828, and his Comprehensive 
Pronouncing Explanatory Dictionary of the English Language, 1830, as well as copies of some of his other works. Worcester was Webster's rival.

- The Henry A. Wallace papers, in the special collections department of the UNIVERSITY of Iowa libraries, will be opened to scholars on January 4, 1971. Wallace, 1888-1965, was editor of Wallace's Farmer, 1924-1933; Secretary of Agriculture, 1933-1940; Vice-president, 1941 -1945; Secretary of Commerce, 1945-1946; editor of New Republic, 1946-1947; and presidential candidate of the Progressive Party, 1948. The Wallace papers at Iowa consist of correspondence, speeches, appointment books, newspaper clippings, issues of magazines, photographs, and other material concerning Wallace's varicd career and wide range of interests, from 1911 to 1965. The University of Iowa is cooperating in indexing and microfilming papers from Wallace's vice-prcsidential term in the Franklin D. Roosevelt library and in the Library of Congress.

- The study of amphibians and reptiles, herpetology, has received special impetus at the UNIVERSITIY of Kansas with the recent acquisition of the personal library of Dr. Edward $\mathrm{H}$. Taylor by the University of Kansas libraries. The collection comprises 850 bound volumes and over 6,000 reprints of articles. Dr. Taylor, Emeritus Professor of Systematics and Ecology at the University, and one of the outstanding herpetologists in the country, spent over fifty years amassing his library. Included are the collected works of more than 125 distinguished biologists of the nineteenth and twentieth centuries, many volumes of which are either extremely rare or irreplaceable today.

- The collection division of the UNIVERSITY of MARYLAND libraries has acquired twentysix letters written in 1923 by William Carlos Williams, one to Glenway Wescott and the remainder to Monroe Wheeler. Williams discusses publication details of Contact $V$, the final issue of a journal founded and edited from 1920 by Williams and Robert McAlmon and published by Wheeler; and Manikin, a venture of Wheeler's which published 'Williams' collection of poems, Go Go, in 1923. Williams comments extravagantly on the Wescott poem which appears in Contact, "Men like Birds," and remarks sharply on the trials of maintaining a family, a medical practice, a journal, and a writing career. With the letters are typescripts of two poems, "Downtown Jazz" and "Puppy Sitting on His Tail."

- A gift of more than 1,000 volumes has been presented to the Slavic book collection of the Manhattanville College library in Pur- chase, New York, by James O'Brien of Bedford Village. Designated as the Callan Memorial Collection, the gift was made by Mr. O'Brien in memory of his grandparents, Mr. and Mrs. Charles James Callan.

Included in the collection are classics of Russian, Polish, Serbo-Croatian, and Slovenian literature, both in their original languages and in translation. Studies in Slavic philosophy and literature, dictionaries, bibliographies, and other reference works also form part of the gift.

Among the most valuable items, according to Sr. Elizabeth O'Connor, director of the library, are an early and rare edition of Valerii Briusov's "The Fiery Angel," the nine published volumes of the Soviet Historial Encyclopedia, and the Academy Dictionary of Serbo-Croatian language, as well as the collected works of major nineteenth century authors.

- The collected correspondence and other papers of the nineteenth century philanthropist William Pryor Letchworth have been deposited on loan in the Milne library, State University College of ARTs and ScIEnce at Geneseo, New York, for purposes of organization and cataloging. Contained in more than 150 letter copy books and manuscript cases, the correspondence will be microfilmed at the library for inclusion in the newly formed Geneseo Valley Historical Collection. Loan of the Letchworth papers to Geneseo is part of a cooperative project developed by Gordon W. Harvey, Regional Director of Parks and Recreation, and Richard C. Quick, Director of College Libraries. The College library will also undertake the cataloging of the five thousand volumes forming Mr. Letchworth's personal library so that these can be suitably arranged for use at Letchworth Park. At Geneseo, Dr. Harry R. Beck of the Department of History will sort and organize the Letchworth papers, abstracting their contents to provide a published guide for the collection.

- Richard Nixon's voice is one of the hundreds of voices represented in a collection of taped interviews presented by Mr. and Mrs. Robert F. Lewis to The Rodgers and Hammerstein Archives of Recorded Sound housed in the Library and Museum of the Performing Arts, the New York Public Library at Lincoln Center. The first tapes of the Lewis collection, including the voices of such other notables as Billy Graham, Maurice Chevalier, Sammy Davis, Jr., and Dr. Albert Sabin, were presented to the Library during a reception in the Vincent Astor Gallery of the Library and Museum.

David Hall, head of The Rodgers and Hammerstein Archives, gratefully accepted the Lewises' gift, noting that it "offers researchers in the oral history field yet another approach to be explored and developed." He particularly appreciated the fact that the interviews represent a 
"virtual cross-section of the USA of our times."

The interviews, conducted by Mr. and Mrs. Lewis between 1962 and 1968, present over 400 figures prominent in the fields of literature, politics, entertainment, the arts, business, medicine, and religion. Most of the interviewees are Americans who, through perseverance, rose from simple origins to positions of great public esteem. The nature of the interviews led the Lewises to call their growing collection "The Library of Achievers."

\section{AWARDS / GIFTS}

- A $\$ 1,000,000$ appropriation from the Andrew W. Mellon Foundation of New York City will enable Princeton Untversity to move forward with long-projected plans for a Social Science Center to be located in its principal library building, the Harvey $\mathrm{S}$. Firestone Memorial Library. The center, which will be known as The Andrew W. Mellon Foundation Center for the Social Sciences, "will essentially be a reference library within a library, or a laboratory for social scientists, physically and symbolically reflecting the increasing interdependence of the social sciences and at the same time meeting the growing need for more advanced specialization," Dr. Goheen, President of the University, said.

"A substantial part of this splendid grant will be used," Dr. Goheen said, "to establish a Mellon Foundation Social Science Book Fund which in this era of mushrooming costs will help provide a solid base of endowed income to insure the currency and development of our collections in the social sciences." The Mellon Center will bring together, Dr. Goheen went on to say, the reference collections in the fields of economics, politics, sociology, and anthropology, and other reference and bibliographic tools, including extensive pamphlet collections and government documents. It will also provide study space for some 70 readers.

- A biennial award given in odd-numbered years, consisting of a citation and a cash award from the income of the Oberly Memorial Fund, will be made to the American citizen who compiles the best bibliography in the field of agriculture or one of the related sciences in the two-year period preceding the year in which the award is made. This award, to be known as the Eunice Rockwell Oberly Memorial AWARD, is made possible by a fund established by colleagues in memory of Eunice Rockwell Oberly. It will be administered by the Agricultural and Biological Sciences Subsection, Subject Specialists Section, Association of College and Research Libraries, a division of the American Library Association. Deadline for nominations is March 15, 1971. Nominations should be sent to the committee chairman, Fleming Bennett, University of Florida Libraries, Gainesville 32601.

- The women's organization, Liaison, reports proceeds of $\$ 4,800$ from its benefit for the Schomburg Collection of Negro Literature and History, a branch of the NEw York Public LIBRARY at 103 West 135th Street. The gift is to be used for restoration and future development of the Schomburg Collection, a reference and research library for black studies. Mrs. Jean Blackwell Hutson, curator of the Schomburg Collection, received the check from Mrs. Kate Harris, acting president of Liaison. Liaison is a group of about thirty black professionals, formed in 1960 to work toward social change and community betterment. It annually sponsors a benefit for a related cause.

- A $\$ 4.5$ million gift from the El Pomar Foundation of Colorado Springs to build a new UNIVERSITY OF DENVER library has been announced by DU Chancellor Maurice B. Mitchell. It is the largest gift from a Colorado source ever made to the University, the largest single gift in El Pomar Foundation history, and the largest in the University of Denver's history to be given without the requirement of matching gifts from other sources. The El Pomar Foundation gift will enable the University to begin preconstruction planning immediately on a new 150,000-square-foot main campus library, to be known as the Penrose Library. The much needed DU facility will relieve overcrowding and inadequate facilities for research and study in the present Mary Reed Library, which was built in 1932 with a gift from Mrs. Verner Z. Reed of Denver.

The new library structure, to which DU officials hope to add another 75,000 square feet later for additional stack and study space, will more than double the space available for library purposes in the campus' present main library. It will also enable DU librarians to consolidate presently separated specialized libraries into the main library building. Such specialized libraries as engineering, business administration, and international studies are now outside the main library and pose a problem of limited accessibility and visibility to both DU faculty and students. Chancellor Mitchell said the University would move forward immediately to complete the architectural design. "We hope to invite bids by spring and be finished 18 months after that-all subject, of course, to variation if delays should occur."

\section{GRANTS}

- A grant of $\$ 82,000$ has been received by the New York Botanical Garden. The money, awarded by the New York Council on the Arts, will allow the Garden library to continue 


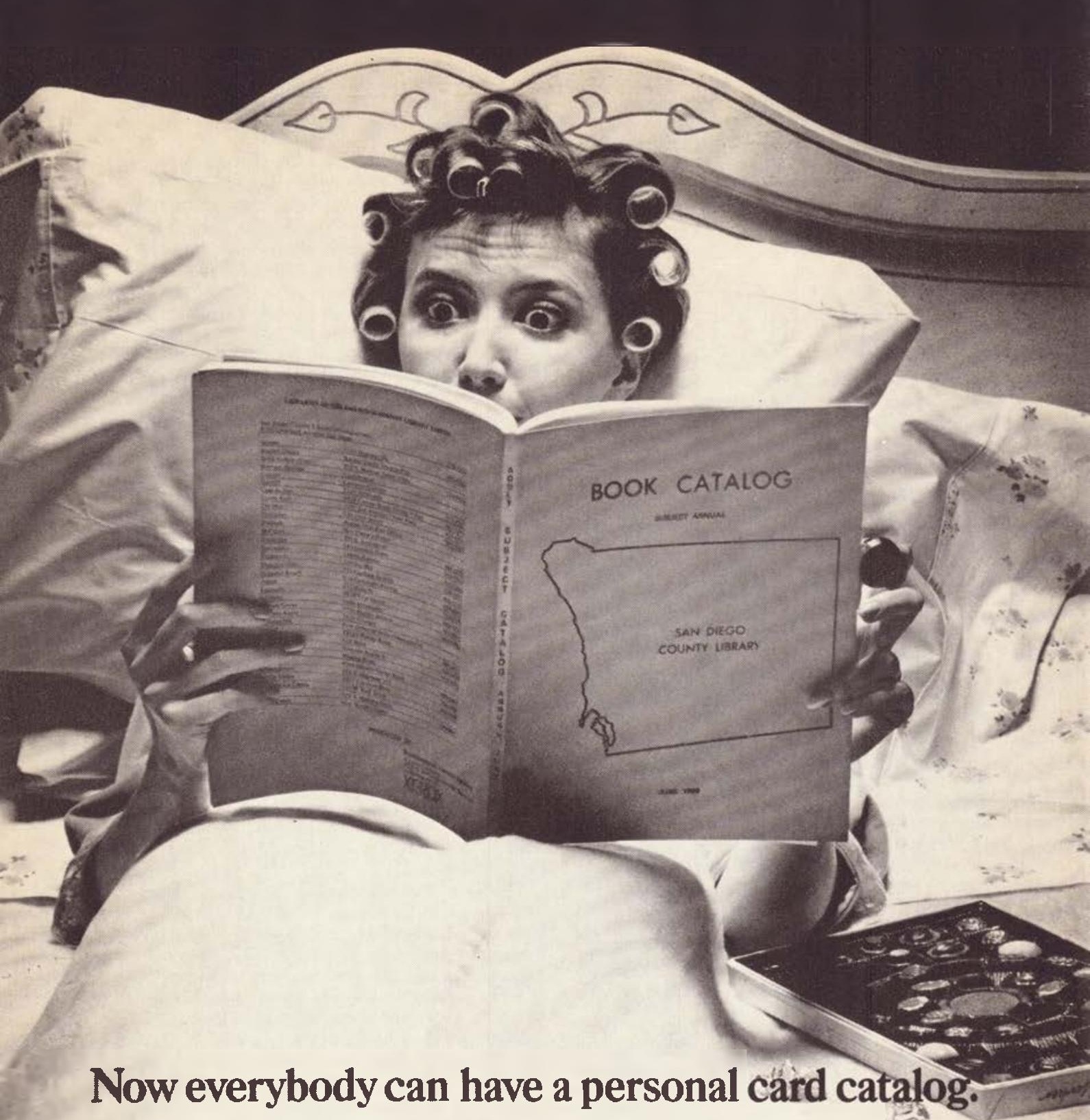

For years your patrons have been going to the card catalog.

Now the card catalog can go to them - in easy-to-scan, easy-to-carry paperback form.

We can convert your entire retrospective file into a book catalog. Or, if your budget won't accommodate that, we can begin with just your current acquisitions. We do the cataloging of the books you want listed at no cost to you. Then, any time you need a new set of revised and up-to-date catalogs, you just order them.

Teachers can keep copies in their classrooms. Large libraries can place one in every department, or lend them out to scholars who request them. Catalogs make it easy for any branch of a large library system to find out which books are held by all the others.

For more information on book catalogs, write: XEROX BiblioGraphics

A Xerox Education Company, 10719 Hanna Street. Beltsville. Md. 20705 
its recataloging, reclassifying, and restoring of several important sections of its collection. Among the materials still awaiting attention are rare books, botanical art of artistic and scientific value, and scientific manuscripts of research done at the Garden. In some cases, irreplaceable objects have been misplaced or have deteriorated for lack of funds necessary to catalog and maintain them. Specifically, the Council's grant this year will provide for expert restoration of books and paintings, for cataloging services, and for staff assistance and materials.

\section{MEETINGS}

JAN. 6-12, 1971: Following on the XXVIIth International Congress of Orientalists Library Panel at Ann Arbor in 1967, Library Seminars will be held during the 28th International Congress of Orientalists, Canberra, 6-12 January, 1971. These may be regarded as the first maior activities of the International Association of Orientalist Librarians set up at the Ann Arbor meetings.

JAN. 26-27, 1971: An Institute on Library of Congress Music Cataloging Policies and Procedures will be held before the official meeting of the Music Library Association. The Institute will try to answer such questions as: what are the general acquisitions policies of the Library of Congress in music books and scores; how are subject headings determined; what is the procedure for changing established subject headings; when are editors' names traced, when not; how is the form of pre- 1700 composers' names established; how and why are Library of Congress cards revised? There will be no charge for the Institute.

Participants will have the responsibility of arranging for their own housing. The Music Library Association has reserved a block of rooms at the following hotels for both the Institute and the Midwinter Meeting of the Music Library Association. Pleasc mention that you are attending the Institute and/or the MIA Mecting at special rates. Hotel Continental, $420 \mathrm{~N}$. Capitol St., Washington, D.C. 20001, Single $\$ 12.00$-Double \$17.00; Capitol Hill Quality Motel, 415 New Jersey Ave. N.W., Washington, D.C. 20001, Single \$18.00-Double $\$ 22.00$. Both hotels are within walking distance of the Library of Congress. Individual reservations for these rooms must be made by the participants before January 1, 1971. In addition, there are two smaller hotels on the same block with rates similar to the Hotel Continental; however, no rooms have been reserved. Dodge House, 20 E. St. N.IV., Washington, D.C. 20001; Hotel Commodore, 520 N. Capitol at F St. N.W., Washington, D.C. 20001. Reservations and further information can be obtained from Vernon Martin, Director, MLA Institutes
Committee, Morningside College, Sioux City, lowa 51106.

FEB. 3-5, 1971: A three-day seminar on indexing to be held February 3-5, 1971, has been announced by the American Library Association and the National Federation of Science Abstracting and Indexing Services. The seminar will be sponsored by the Subject Analysis and Organization of Library Materials Committee, Cataloging and Classification Section of ALA's Resources and Technical Services Division. It will be hosted by Pratt Institute, Graduate School of Library and Information Sciences in its Manhattan Center at 46 Park Avenue, New York City.

The cost of the three-day seminar is $\$ 75.00$. The registration fee includes a special kit being prepared for the course. Full details may be obtained from the National Federation of Science Abstracting and Indexing Services, 2102 Arch Street, Philadelphia, Pennsylvania 19103; or from Miss Carol Raney, Executive Secretary, Resources and Technical Services Division, American Library Association, 50 East Huron Street, Chicago, Illinois 60611.

Further details are also to be found in the December News, Mectings section.

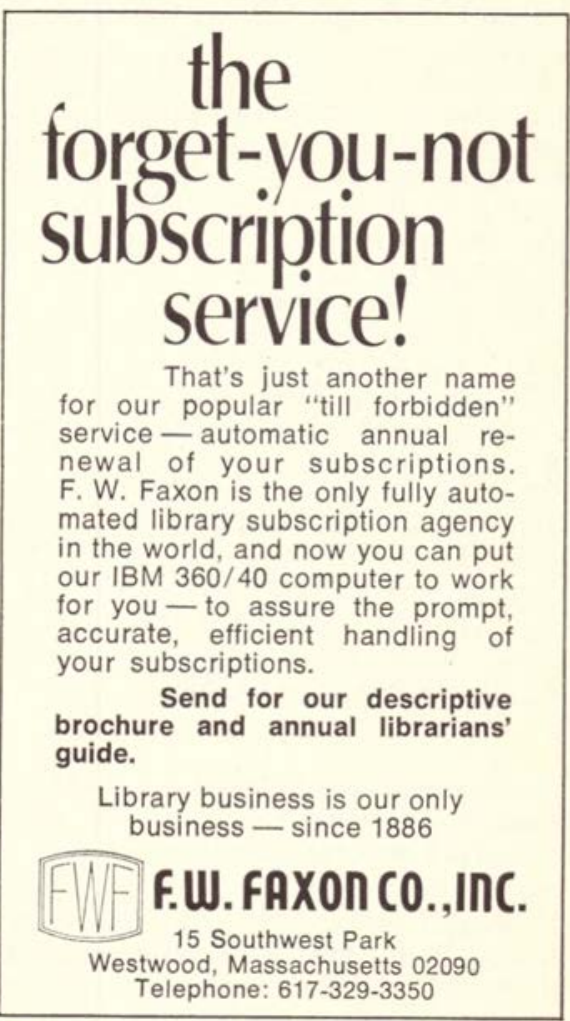


FEB. 17-19, 1971: The third international seminar on "Approval and Gathering Plans," sponsored by the Florida Atlantic University Library and Division of Continuing Education, will be held in West Palm Beach, Florida, on February 17-19, 1971. The two-day seminar is designed to assist those who have recently started with approval plans or are contemplating starting one.

The attendance will be limited to individuals who participate in the decision-making process affecting acquisitions policies and practices in their respective institutions.

FEs. 22-24, 1971: The 1971 Conference of the National Federation of Science Abstracting and Indexing Services will be held from February $22-24,1971$, in Washington, D.C. More information from National Federation of Science Abstracting and Indexing Services, 2102 Arch Street, Philadelphia, Pennsylvania 19103.

Details on program, organization, and topics are to be found in the December News, Meetings section.

Mancir 11-13, May 13-15, 1971: To provide library administrators an opportunity to learn about the solutions of management problems related to automation, two workshops in administrative and management aspects of library automation have been scheduled by the Information Science and Automation Division of the American Library Association (ALA ISAD). The workshops will approach problems in initiating and planning an automation program, subsequent implementation, operations, melding the automation program into the library environment, and in other management functions. All meals and lodging will be included in one fee to ensure that the attention of each registrant can be sharply focused. Registrations will be limited to 50 persons per workshop. They will be accepted on a first come, first served basis from librarians in administrative positions that include automation management responsibilities. Workshops are scheduled for Asilomar Conference Grounds, Pacific Grove, California, March 11-13, 1971; and for MIT Endicott House, Dedham, Massachusetts, May 13-15, 1971. Information and application forms may be obtained from ISAD Institutes, American Library Association, 50 East Huron Street, Chicago, Illinois 60611.

APr. 23-24, 1971: Sixteenth annual Midwest Academic Librarians Conference at Indiana University, Bloomington, Indiana.

May 30-June 3, 1971: The 70th Annual Meeting of the Medical Library Association will be held in New York City, May 30June 3, 1971 .
JuLy 11-13, 1971: The School of Library and Information Services, University of Maryland, is planning the fifth annual Library Administrators Development Program to be held JuLy $11-$ 23, 1971. Dr. John Rizzo, Professor of Management, Western Michigan University, will serve as the director. As in the past four summers, participants will include senior administrative personnel of large library systems (public, research, academic, special, governmental, and school) from the United States and Canada. The faculty is made up of well-known scholars, educators, management consultants and lecturers drawn from universities, government, and consulting fields. Seminar sessions will concentrate on the principal administrative issues which senior managers encounter. Leadership, motivation, communication, personnel policy, decision-making, problem solving, financial planning and control, performance appraisal, the impact of technology, and the planning of change are among the issues considered in lecture, case analysis, group discussion, and seminar.

The two-week resident program will again be held at the University of Maryland's Donaldson Brown Center, Port Deposit, Maryland, a serene twenty-acre estate overlooking the Susquehanna River and offering a variety of recreational facilities and an informal atmosphere conducive to study, reflection, and discussion. Those interested in further information are invited to address inquiries to Mrs. Effie T. Knight, Administrative Assistant, Library Administrators Development Program, School of Library and Information Services, University of Maryland, College Park, Maryland 20742.

JuL.y 20-23, 1971: The third Cranfield International Conference on Mechanised Information Storage and Retrieval Systems will be held July 20-July 23, 1971, in Bedford, England.

See the December News, Meetings section, for complete details on the topics to be covered and general theme outline.

Enquiries or offers to present papers should be sent to the Conference Director, Cyril Cleverdon, Cranfield Institute of Technology, Cranfield, Bedford, England.

Avg. 22-27, 1971: An International Conference on Information Science will be held in Israel August 22-27, 1971. For information write Conference Secretary, ISLIC-Israel Society of Special Libraries and Information Centres, P.O.B. 16271, Tel-Aviv. See also September CRL News, page 249.

SePt. 30-Oct, 2, 1971: The Indiana Library Association will meet at Stouffer's Inn, Indianapolis, Indiana. Further information can be obtained from Jane G. Flener, President, 
Indiana Library Association, Indiana University Library, Bloomington, Indiana 47401.

\section{MISCELLANY}

- The national headquarters of Alpha Beta Alpha National, Undergraduate Library Science Fraternity proudly announces the installation of five chapters this year.

Alpha Pi Chapter-Mansfield State College, Mansfield, Pennsylvania 16933 installed on April 4, 1970; Alpha Rho Chapter-Austin Perry State University, Clarksville, Tennessee 37040 installed on April 9, 1970; Alpha Sigma Chapter-Sam Houston State University, Huntsville, Texas 77340 installed on March 20, 1970; Alpha Tau Chapter-Slippery Rock State College, Slippery Rock, Pennsylvania 16057 installed on April 25, 1970; Alpha Upsilon Chapter-State College of Arkansas, Conway, Arkansas 72032 installed on May 12, 1970.

- The School of Library Science of CASE Western Reserve University (CWRU) in Cleveland, Ohio, is offering a special program in law librarianship beginning in the 1970-71 academic year. The program leads to the Master of Science in Library Science degree and combines advanced study in library and information science and in law. Designed to enable students to acquire adequate legal background for work in any type of law library, the program introduces students to the literature of law, its bibliographic sources, techniques of basic legal research, legal method and administrative law, and orients them to the objectives and problems of librarianship as a whole. A special feature of the program will be planned, practical experience under the supervision of the CWRU law librarian. Inquiries concerning the program and admission requirements to the School may be addressed to Admission Office, School of Library Science, Case IVestern Reserve University, Cleveland, Ohio 44106.

- Sample copies of library users' handbooks, guides, and other orientation materials are sought by the Feneral Library Committee Task Force on Public Relations in an effort to augment the loan collection of such materials. Mrs. Lois Fern, chairman of the Task Force, has asked that gift copies be sent to her attention at the Federal Library Committee, Room 310, Library of Congress, Washington, D.C. 20540 .

Mrs. Fern has noted that the Task Force on Public Relations is currently examining ways in which it may assist in creating attractive, informative library guides. Under consideration are the development of a handbook, the sponsorship of a workshop or series of workshops, and the expansion of the loan collection concept.
- A library to fight crime is being assembled at The University of Texas School of Law. Funded by a $\$ 40,000$ grant from the Texas Criminal Justice Council, the special collection will consist of books, studies, and special reports in the field of criminal justice. The primary objective of the special collection, according to Professor Mersky, professor of law and director of the project, will be to meet the informational needs of Texas police, correctional institutional agencies, legal defender offices, district attorneys, and juvenile and criminal courts. The collection will be located in UT Austin's Tarleton Law Library, and the library's staff will assist in setting up the project.

"Presently we plan two types of publications for the collection," says Mrs. Jane Olm, librarian for the special collection. "We will publish bibiographies on the contents of the collection and hopefully a monthly newsletter for interested agencies and individuals in the criminal justice field." Research facilities in the Tarleton Law Library will be made available to the staff of the Texas Criminal Justice Council as well as local and regional planning agencies in the criminal justice field.

- The University of Iluinors Graduate School of Library Science is offering a unique program leading to the Master of Science degree with specialization in biomedical librarianship. The program is supported by a grant from the United States Public Health Service and administered by the National Library of Medicine. This grant allows the School to offer ten traineeships annually to qualified participants. The program requires thirteen months of full-time study for completion. It begins in mid-June of one year and ends in mid-July of the following year. Trainees are paid a stipend of $\$ 2,600$ plus an allowance of $\$ 542$ for each dependent, payable over the thirteen-month period. Tuition and fees are also waived.

The curriculum is designed to give a thorough grounding in modern library services and administration and in the special problems encountered in handling medical literature, including information retrieval. In addition, the trainee is given some practical experience in scientific bibliographic work. To be considered for admission, applicants must meet the following minimum requirements: a bachelor's degree from an accredited institution; a major in a field other than library science; a grade-point average of at least 3.75 (on a 5.0 scale) for the last sixty hours of academic work completed; and twelve or more semester hours of coursework in the biological sciences. Trainees are chosen from among the best qualified applicants who meet these and other admissions requirements of the Library School. For further 


\section{Jefferson Himself}

Bj BERnARD MaYo, University of Virginia. $x v, 384$ pp., frontis., illus., notes, index.

Cloth, $\$ 6.75$. Paper $\$ 3.00$

"It is hardly too much to say that this volume will, henceforth, be the most useful introduction to Jefferson in print; for more directly and vigorously than any biography, it will teach readers what an endlessly fascinating person Jefferson, so versatile, so vibrantly alive, so keen of vision, was - and is."

-Allan Nevins

"This skillful and well-edited selection from Jefferson's own writings provides an admirable introduction to him. It has lost none of its freshness and I am delighted that it is to appear again in print."

-Dumas Malone

\section{History of Virginia}

\section{By Edmund Randolph}

Edited by Arthur H. Shaffer. Introduction by Arthur H. Shaffer and John MElville JenNings.

xliv, 347 pp., illus., index. (VIRGINIA HISTORICAL SOCIETY)

$\$ 10.00$

Historians have long been aware of the existence of a history of Virginia written by Edmund Randolph late in the eighteenth century. His History of Virginia gives an account of Virginia from the colonial period through the end of the revolutionary war. As Randolph put it in his Preface, "Virginia will be seen rising from infancy and a wilderness, through various fortunes, into wealth, a character, and an influence which largely contributed to the establishment of American independence and to the formation of that most illustrious among civil acts, the Constitution of the United States of America."

\section{The Legitimacy of the Business Corporation in the Law of the United States $1780-1970$}

By James Willard Hurst, University of Wisconsin. xiii, 191 pp., bibliog., index.

These three essays deal with public policy with respect to the business corporation in the United States from 1780 into the $1960^{\circ}$ s. They trace the development of the business corporation from the time it was treated as a matter of special privilege to the end of the nineteenth century when corporation became available to all qualified applicants under general legislative and simple administrative procedures. The author establishes that the deepest roots of law of the business corporation drew from general life, and not just from law. This study includes full documentation with detailed references to all relevant legal materials and is the most complete study of privately organized power available.

\section{The Cornwallis Papers \\ Abstracts of Americana}

Compiled by GEORGE H. REESE, University of Virginia. xiv, 229 pp., index. (JAMESTOWN FOUNDATION)

$\$ 7.50$

This collection of abstracts of all the items of Americana in the Cornwallis Papers is now available for the first time. It is an excellent reference tool for the historian of the Revolutionary War. The Cornwallis Papers, located in the Public Record Office of London, include the writings of Charles Cornwallis, better known to Americans as the General Cornwallis who surrendered to American forces at Yorktown, Virginia, in 1781. The personal and military papers which Cornwallis wrote and received during the British campaigns in the American Revolutionary War are calendared and abstracted here in detail. They provide one of the best resources available of the British conduct of the war. A thorough index of the papers follows the abstracts, providing further identification of the officers and the civilians with whom General Cornwallis dealt. 
information and for application forms, write: Associate Professor F. Wilfrid Lancaster, Graduate School of Library Science, University of Illinois, Urbana, Illinois 61801.

- A new chapter of Beta Phi Mu, international library science honorary, was installed November 13, 1970 at the UNIversity of DENVER's Graduate School of Library Science. The society now has twenty-four chapters and approximately 8,000 members.

- The New York Public Librany has opened the Mid-Manhattan Library at 8 East 40 th Street. While the new facility was designed to serve as a reference center for undergraduate college students and business and professional men and women, it will be open to all types of patrons. The facility is located on the fourth and fifth floors in the renovated 40th Street building and in two rooms on the ground Hoor of the central building of the main library. The collections will include general reference, science, history and social science, literature and language, and popular; the latter two collections will be located in the central building. The renovation of the building was funded through two million dollars in private funds supplemented by $\$ 500,000$ in LSCA funds. The equipment and books were purchased with city funds.

- The National Technical Information Service (NTIS) has been established in the $\mathrm{DE}_{\mathrm{E}}$ PARTMENT OF COMMERCE to simplify and increase public access to federal publications and data files of interest to the business, scientific, and technical communities. Secretary of Commerce Maurice H. Stans, in establishing NTIS, stated that "the Clearinghouse for Scientific and Technical Information (CFSTI) in the National Bureau of Standards has been transferred to the NTIS, and its functions merged with a broader mission for NTIS." Peter F. Urbach was appointed deputy director of the National Technical Information Service and designated to serve as acting director. Urbach was deputy director of CFSTI in 1967-68. The NTIS is a primary operating unit of the Department, reporting to Dr. Myron Tribus, assistant secretary for Science and Technology. Dr. Tribus said that the NTIS would enlarge considerably the range of services presently available through the Clearinghouse and would seek to increase the use of its publications. Each year, nearly 50,000 titles have been added to this collection, and more than two million copies of reports are sold. It is expected that these figures will grow substantially under the new arrangement. All questions, comments, and requests for descriptive material concerning NTIS should be directed to Mr. Eric Tietz, National Tech- nical Information Service, 5285 Port Royal Road, Springfield, Virginia 22151.

- Rutgers University has dedicated the new Library of Science and Medicine on University Heights Campus in Piscataway, Maryland. An unusual feature of the library is a facsimile transmission system over telephone circuits to connect it with the National Agricultural Library. It will also have ready access to the National Library of Medicine in Bethesda, Md. The 86,000-square-foot library contains storage space for more than 200,000 volumes, and already has 120,000 on hand. Costing more than $\$ 3$ million to construct, the building was financed by funds from the 1964 Bond Issue, the Title II program of the U.S. Department of Health, Education, and Welfare, and the National Library of Medicine Construction Act. Construction began in May 1968, and was completed late this summer. The building contains seminar rooms, study space for 500 persons (room for 70 is in an area open twenty-four hours), and soundproofed rooms for activities such as typing and tape recorder operation.

- The School of Library Science of the STATE UNIversity of NEw YoRk at Albany has received 20 trainee grants for $1970-71$ to initiate a three-year undergraduate and graduate program leading eventually to the bachelor's degree in a chosen field and to the master's degree in library science. The grants are made possible through funds from the U.S. Office of Education, as authorized by Title II-B of the Higher Education Act of 1965. Arthur R. Kirwin, Jr., formerly of Schenectady Community College Library, has been appointed coordinator of the program. Miss Pamela A. Carrington, a recent graduate of the School of Library Science, has been named assistant coordinator. The librarianship trainee program has recruited 20 students (seven men, 13 women) for the program, all of whom are now registered at SUNYA. They represent a wide variety of backgrounds, some having graduated from community colleges and others having completed two years in a four-year institution. Their undergracluate majors are diverse and range from the social sciences and humanities through the natural sciences and applied sciences. Library science is a required second field for the trainees.

In the summer following the junior year, there will be a six-week library intern experience. Through the junior and senior years at SUNYA, the 20 trainees will be involved in the affairs, social and academic, of the School of Library Science. A program of field trips and speakers is being planned for the 1970-71 school year.

The grantees were chosen for the program on the basis of the following criteria: meeting the minimum academic qualifications for trans- 
"The aid to government publications most needed by librarians."

Boyd and Rips, United Slates

Government Publications, 3rd Ed. 1958

\section{UPDATES THE 1909 CHECKLIST AND OTHER BASIC REFERENCE TOOLS USED BY DOCUMENTS LIBRARIANS}

Here's how the two standard reference books on U.S. Government documents evaluate the Public Documents Library, its collection, the SuDocs Classification scheme, and the need for updating the predecessors of Checklist '70.

Government Publications and Their Use, L. F. Schmeckebier and R. B. Eastin, 2nd Revised Edition, Brookings Institute, 1969.

"There is probably no complete collection of government publications in existence, but the one in the Public Documents Library is probably the most nearly complete .... it has all issues listed in the Monthly Catalog and the biennial Documents Catalog. It also has some material not so listed, as back issues are often sent to the library after the catalogs are printed."

United States Government Publications, A. M. Boyd and R. E. Rips, 3rd Revised Edition, Wilson, 1953.

"The Library of the Office of Superintendent of Documents is of interest to librarians . . because of the classification scheme by which its collection is arranged. It has been adopted by many other libraries throughout the country as a most convenient and satisfactory method of organizing and arranging collections of government publications.

"There have been three checklists of government publications. ... The third, which was much more inclusive and a monumental work of incalculable value covering the entire period of United States publications to 1909 ... was published in 1911.

"A fourth edition, bringing the third edition to date, is the aid to government publications most needed by librarians."

\section{CUMULATIVE SUPPLEMENTS WILL UPDATE THE COLLECTION}

Thanks to GPO's full cooperation, we are also able to offer subscriptions to a service which will update the shelf lists semiannually in dual-media cumulative supplements. The microfilm portion will include all new entries added to the shelf lists after the 1970 cut-off date. They will be filmed in SuDocs Classification order, and the accumulated files issued semiannually until such a time as the entire shelf lists will be re-filmed in one sequence. The four indexes will be issued in paperback supplements and accumulated along with the card files.

\section{The United States Histo}

by special arrangement wi and the Acting Superintenden
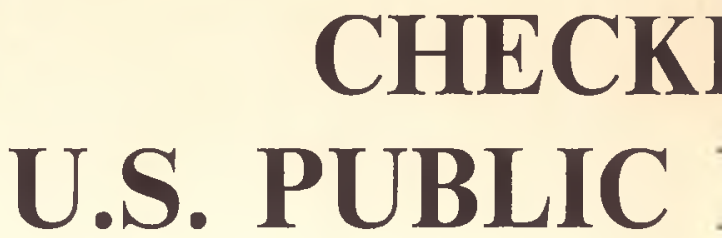

1789-1970

$\ldots$ a

lists 0

merits

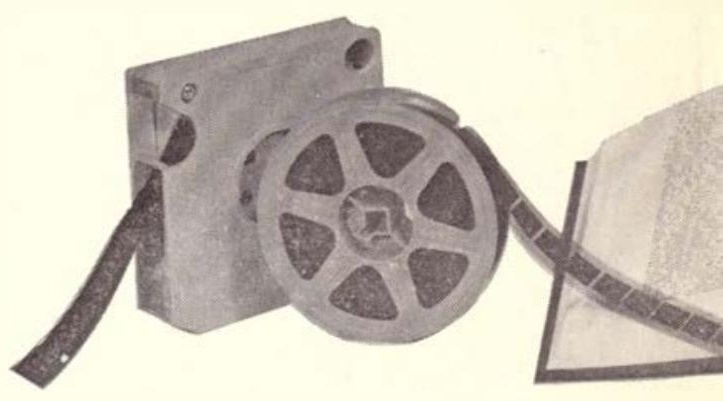

\section{ON MICROFILM}

$1,200,000$ shelf list cards on $16 \mathrm{~mm}$ microfilm (roll or cartridge);

arranged in SuDocs classification order by some 3000 government authors; and

current as of October 1970.

The active file contains approximately 550,000 cards describing publications of existing government authors and continuous series.

The inactive file contains 650,000 cards describing publications in discontinued series and items published by government authors that are no longer active.

Also, both files contain about 50,000 guide cards which indicate changes of titles and identify predecessor and successor organizations.

\section{SEPARATE SUBSETS OFFERED FOR MAJOR GOVERNMENT AUTHORS}

Department level author breakouts are available separately upon request. For example, you may order individual microfilm reels covering the shelf lists of publications of the Department of Agriculture, Interior Department, Health, Education and Welfare. Please write for price information. 


\section{ical Documents Institute}

$h$ the U.S. Public Printer

of Documents announces the

IST OF

DOCUMENTS

dal media collection of the Active and Inactive shelf the Superintendent of Documents', Public Docuibrary, Washington, D. C.

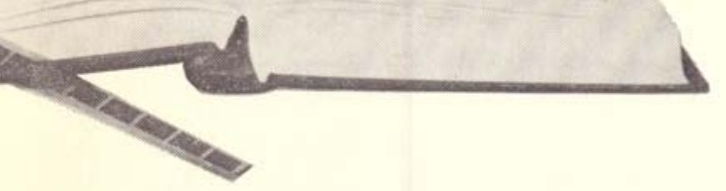

\section{IN BOUND VOLUMES}

Four full-size, hard cover computer-based indexes compiled by Daniel and Marilyn Lester. Mr. and Mrs. Lester are the Associate Director for Systems and Automation, and Technician, Government Publications Division, at the Library of Mankato State College in Minnesota.

INDEX ONE - arranged by author in SuDocs class order showing microfilm reel numbers (in essence, a detailed Table of Contents for the Microfilm Segments).

INDEX Two - arranged in a single alphabet format by some 3000 individual government authors (both active and inactive). This index brings together all SDC numbers for any government Author, regardless of its reorganization history. INDEX THREE - an alphabetical listing of cabinet level departments and major agencies subdivided by their individual publishing offices listed alphabetically.

INDEX FouR - an alphabetical listing of some 18,000 U. S. Government series titles giving SDC Class numbers and microfilm reel numbers. This list will be enlarged with full descriptive data for each series in the Lesters' forthcoming Bibliography of U.S. Government Serial Publications, 1789-1970.

Note: All index entries show SDC and microfilm reel numbers.
"The most comprehensive single source of published information on U.S. Government Documents."

Carper W. Buckley

U.S. Superintendent of Documents 1958-1970

\section{BIBLIOGRAPHIC DATA ON MORE THAN 1.5 MILLION U.S. GOVERNMENT PUBLICATIONS}

Now available to librarians for the first time in any format. As stated by Carper W. Buckley, who until his retirement in 1970 had served as U.S. Superintendent of Documents since 1953.

"Checklist'70 provides librarians with the most comprehensive single source of published information about United States Government documents. It lists all titles which appear in the shelf lists of the Public Documents Library of the U.S. Government Printing Office, covering the period 1861 through October 1970. Also included are the publications listed in the Checklist of U.S. Public Documents, 1789-1909, the Monthly Catalog and Mary Elizabeth Poole's Documents Office Classification to 1966."

In addition to containing bibliographic citations and SuDocs Classification numbers for the publications mentioned above, Checklist ' 70 also contains references to thousands of publications which held security classifications when originally published and therefore did not appear in any lists or bibliographies. Most of these which were later declassified and added to the Public Documents Library's shelf lists were never picked up retrospectively in the standard bibliographic reference tools.

Each citation is at least as complete as the entries in the Monthly Catalog and often provides more information. For instance, bibliographic data on each issue of certain periodicals are included, as well as complete cross-references for changes in classification numbers, titles, or issuing agencies. Cutterized separates are listed for some series publications.

Monographic publications can be found by Cuttered keyword under the "Gencral Publications" heading for most major departments and agencies.

\section{IMMEDIATE DELIVERY} ON MICROFILM SHELF LISTS INDEX VOLUMES AVAILABLE SPRING 1971

TO: U. S. Historical Documents Institute 1647 Wisconsin Ave., N.W., Wash., D. C. 20007

\section{Please record our order for:}

$\square \quad$ The Dual-Media, Checklist of United States Public Documents, 1789-1970. (116 microfilm cartridges and 4 index volumes) $\$ 2,550$.

$\square$ Semi-Annual Cumulative Updating Service, 1971 Annual Subscription (includes cumulations as of June 30 , and December 31st, 1971)

$\$ 275.00$

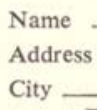


fer to the State University of New York at Albany; commitment to three years of education leading to the bachelor's degree and to the master's in library science; commitment to eventual entrance in the library and information science profession; and economic inability to finance this further education through family or personal resources.

\section{PUBLICATIONS}

- The Black Experience in the United States: A Bibliography Based on the Collections of the San Fernando Valley State College Library has been published and is available through Richard Abel \& Company for \$12.00. The bibliography, which was designed and printed by Anderson, Ritchie and Simon (the Ward Ritchie Press) contains 3,175 entries, mostly books, in shelflist order (Library of Congress classification) and an author index. The bibliography was intended primarily to be a supplementary finding tool for SFVSC students interested in black studies, but widespread interest in an earlier, shorter version prompted the library to produce this edition as an example of a well-designed book and as a substantial reference tool.

- A seventy-five-page index to Beryl Rowland's Companion to Chaucer Studies, New York, Oxford University Press, 1968, is available for $\$ 2.00$ from Linda K. Rambler, Reference Librarian, Lehigh University, Bethlehem, Pennsylvania 18015. The index was compiled under the direction of J. Burke Severs, Professor Emeritus, Lehigh University, and Albert E. Hartung, Professor and Chairman of the Department of English, Lehigh University.

- Dr. Susan Crawford and Dr. Frank L. Schick have compiled a Directory of Health Sciences Libraries in the United States, 1969. Published by the American Medical Association, this directory is the first such venture of national scope. It identifies a total of 3,155 library collections in the fifty states, the Canal Zone, Guam, and Puerto Rico.

Of the total number of libraries identified, almost two-thirds are located in hospitals. Four hundred seventy-one libraries and collections are located in colleges, universities, and professional schools. They include the health sciences libraries serving 101 existing medical schools, as well as the six medical schools in developmental stages during 1969. Sixty-one percent of the libraries are private; besides academic and hospital libraries, these include a substantial number of comparatively small collections in societies, foundations, and pharmaceutical companies. Approximately half of the public institutions are state controlled; these include 44 public health agency collections.
- East Asian Periodicals and Serials ... A Descriptive Bibliography, Bibliographic Series: Number one, revised, is available through the University of Pittsburgh Book Center, 4000 Fifth Avenue, Pittsburgh, Pennsylvania 15213 for $\$ 3.00$ per copy prepaid, plus postage. It contains over 600 titles in the University of Pittsburgh East Asian Library.

- The Ohio State University Libraries Publications Committee announces the publication of Carol Beasley Healer's Instruction P'rogrammed for Education in Textiles (84p. LC70-6322246). Mrs. Healer, a member of the Home Economics Faculty of the University of Akron, traces the development of interest in programmed instruction and its applications to home economics education. Included are two actual programs which have been used for instruction in textiles together with an informed assessment of their effectiveness and recommendations for improvement. A brief discussion of trends and future uses of programmed instruction in textile education and home economics curricula closes the study. This is a useful overview for home economics teachers and for other educators who are thinking of using programmed materials and would like to become aware of the problems and rewards. Copies are available at $\$ 3.00$ each from the Ohio State University Libraries Publications Committee, Room 322A, 1858 Neil Avenue, Columbus, Ohio 43210.

- The second edition of the Intermountain Union List of Serials is now available. This edition includes the revised periodical data from the first edition and newly reported serial information. The number of libraries participating in the project is up from fifteen in the first edition to forty-one in the second.

The new edition includes data for 20,000 titles. Two hundred copies of the two-volume set will be published.

Distribution is free within the state of Arizona to tax-supported institutions and participants in the project. Out-of-state distribution costs $\$ 40.00$ per copy. All sales receipts go into project funds for production of a supplement and continued maintenance of the data. Orders should be sent to Arizona State University Library (IMULS Project), Tempe, Arizona 85281 .

- Okate Iyechinka Woglakapi, Volume 1 of the list of oral history tapes on American Indian History, has been published by the American Indian Research Project of the University of South Dakota. It is available from the project at the University of South Dakota, Vermillion, South Dakota 57069. Although a few white men were interviewed, the emphasis of the project is on seeking our older Indians who can 


\section{In December 1970 \\ Mansell published the I 20 th volume of the National Union Catalog, Pre-I956 Imprints}

With the file complete almost through $\mathrm{C}$ and five volumes being added each month, the incomparable value of this great bibliography is being proved daily in well over a thousand libraries world-wide Full particulars and details of regular and deferred subscription plans from Mansell,

3 Bloomsbury Place, London wcr, England We sball be at ALA Midwinter and shall be very pleased to see you at our Los Angeles Biltmore suite 
contribute to a better understanding of Indian history and culture.

- The Newberry Library Associates has published An Uncommon Collection of Uncommon Collections: The Newberry Library. The booklet presents an informal history of The Newber- ry Library and descriptions of the many quality special collections held by the Library. The booklet is available from the Publications Department, The Newberry Library, 60 West Walton Street, Chicago, Illinois 60610 for $\$ 1.00$ per copy.

\section{News from the Sections}

ART SUBSECTION

The fourth edition of the Class N, Fine Arts, Library of Congress Classification, has appeared this fall. Thanks to the work of William B. Walker, librarian of the National Collection of Fine Arts/National Portrait Gallery Library and vice-chairman of the Art Subsection, this new issue represents not only an incorporation of all additions and changes made since the third edition up to October 1969, but also a thoroughgoing revision. Perhaps the most striking innovations of this revision are the regrouping of numbers for similar types of publications which had heretofore been dispersed in several places (e.g. works on art collectors and patrons have been brought closer to material on private collections), and the combining, in the same numerical sequence, of works on the history of art in a particular medium with books of reproductions of works in the same medium. In all cases where class numbers are no longer

APPOINTMENTS

Mrs. EMIKo Axiyama, who has been serving as acting librarian of the Cornell Medical College, continues in the library and will henceforth direct all of its service functions.

Mrs. Donna Baker is on the staff of the Tompkins-McCaw library, Health Sciences Division, Virginia Commonwealth University, Richmond, as assistant cataloger.

Mrs. Ivy Bayard is now head librarian, Tyler School of Art library, Temple University, Philadelphia.

Sylvia Belx has been promoted to the position of acquisitions librarian, librarian III, library of Osgoode Hall Law School, York University, Toronto, Ontario, Canada.

Mrs. Gwynnetr H. Bishop is now head of the science and medicine department of the University of Toronto library, Ontario, Canada.

Mrs. Helma Bonfield has been appointed librarian I, cataloging department, York University libraries, Toronto. used by the Library of Congress, they have been parenthesized for continued use by other libraries which may not wish to adopt these changes, and appropriate references have been made. The task of updating the schedules and increasing their comprehensiveness will reap many rewards. A new subclass NX has been added, dealing with the arts in general, including literature and the performing arts as well as the visual arts. The geographic tables which can be applied throughout the schedule have been updated to reflect the current jurisdictional situation. The edition has been printed on one side of the page only, thereby providing a suitable format for libraries using the schedule to make annotations, punch the pages for a looseleaf binder, and insert pages from the $L C$ Classification-Additions and Changes for updating. Copies may be obtained from the Card Division, Library of Congress, Building 159, Navy Yard Annex, Washington, D.C. 20541, at $\$ 3.00$ a copy.

\section{Personnel}

Hartwell Bowsfield is now university archivist, on a part-time basis, at York University libraries, Toronto.

M. Diane Brown has joined the staff of the cataloging department of the York University libraries, Toronto, as librarian I.

Mrs. LouISE BUGG has been promoted to the position of head, catalog department, Kresge library, Oakland University, Rochester, Michigan.

Mrs. Etta S. Bullock has been appointed librarian, community and cultural affairs, Temple University libraries, Philadelphia.

Mrs. Patricia J. Bunker has joined the staff of Rush Rhees library, University of Rochester, New York, as assistant librarian.

Mrs. Nancy BUrich has assumed a position as reference librarian, Medical library, Columbia University.

Ralph L. Carder is in the Library Resources Center, Wright State University, Dayton, Ohio, in the capacity of graphic supervisor and instructor of library administration. 